\title{
CARBOHYDRATE METABOLISM IN PREGNANCY. I. THE METABOLISM OF INSULIN BY HUMAN PLACENTAL TISSUE * $\dagger$
}

\author{
By NORBERT FREINKEL AND CHARLES J. GOODNER $\ddagger$
}

\author{
(From the Thorndike Memorial Laboratory and Second and Fourth (Harvard) Medical Serv- \\ ices, Boston City Hospital, and the Department of Medicine, Harvard Medical School, \\ Boston, Mass., and the Howard Hughes Medical Institute)
}

(Submitted for publication July 22, 1959; accepted August 19, 1959)

Much clinical evidence would suggest that there is a change in carbohydrate metabolism during pregnancy (2-8). In the past, the diabetogenic effects of pregnancy have been attributed to an increased elaboration of hormonal contrainsulin factors. An alteration in the degradation of insulin during pregnancy might constitute a supplemental or alternative mechanism. It has been shown by Mirsky, Perisutti and Dixon $(9,10)$ and Tomizawa, Nutley, Narahara and Williams $(11,12)$ that various animal tissues, such as liver, contain relatively specific enzymes for the proteolytic inactivation of insulin. To date, such systems have not been studied in isolated preparations of human tissues. In the present study, the presence of an active, enzymatic mechanism for the proteolytic degradation of insulin has been demonstrated in human placental tissues. The characteristics of the system have been defined and its potential contributions to maternal insulin economy have been evaluated.

\section{MATERIALS}

1. $I^{131}$-insulin. Crystalline beef insulin (Lilly zinc insulin No. 535664 assaying 27 units per mg.) was purchased from Abbott Laboratories, Oak Ridge, Tennessee, in solutions containing $0.1 \mathrm{mg}$. insulin per $\mathrm{ml}$. It had been labeled with $\mathrm{I}^{131}$ to an initial specific activity of 4 to $7 \mathrm{mc}$. per $\mathrm{mg}$. The iodination entailed the substitution "approximately one atom of iodine per molecule of insulin, assuming a molecular weight of 6,000 for the insulin" (13). Upon receipt in this laboratory, the $\mathrm{I}^{121}$ insulin was immediately diluted with four parts of phosphate-buffered sodium chloride (116 mMoles per L.)

* This investigation was supported in part by Research Grant A-1571 (C) and Training Grant 2A-5060 (C2), National Institute of Arthritis and Metabolic Diseases, United States Public Health Service, Bethesda, Md.

$\dagger$ Presented in part at the joint meetings of the American Society for Clinical Investigation and American Federation for Clinical Research, May 4, 1958, Atlantic City, N. J. (1).

\$ Public Health Service Research Fellow of the National Institute for Arthritis and Metabolic Diseases. containing 5 per cent human serum albumin (HSA). Thereafter, the material was dialyzed at $4^{\circ} \mathrm{C}$. for 24 hours against serial changes of sodium chloride (135 mMoles per L.) buffered at $\mathrm{pH} 7.4$ with sodium phosphate (10 mMoles per L.). The resultant dialyzed and buffered albumin-insulin mixtures were employed as stock solutions. No stock solution was employed for more than 10 days. Between experiments, stock solutions were stored in the frozen state.

More than 98 per cent of the total radioactivity in the stock $\mathrm{I}^{131}$-insulin solutions could be precipitated with trichloroacetic acid (TCA). Various preparations were analyzed for homogeneity by hydrodynamic flow paper chromatography (14) and by paper electrophoresis on Whatman No. 3 filter paper, in barbituric acid-sodium barbiturate buffer, $\mathrm{pH} 8.6, r / 20.05$. As judged by the latter criteria, products of radiation damage or spontaneous degradation did not exceed 7 per cent of the total radioactivity. When three separate stock solutions were diluted to $1 \times 10^{-4}$ units per $\mathrm{ml}$., their hypoglycemic potency in the rat epididymal fat pad assay system (15) was not significantly different from that of comparable quantities of unlabeled crystalline insulin.

For individual experiments, stock solutions of $\mathrm{I}^{181}$ insulin were supplemented with unlabeled "glucagon-free" crystalline zinc insulin. ${ }^{1}$ The unlabeled insulin had been dissolved in water with the addition of a few drops of $0.01 \mathrm{~N} \mathrm{HCl}$ and solutions of $2 \mathrm{mg}$. insulin per $\mathrm{ml}$. were maintained at $\mathrm{pH} 3.9$ during storage at $4^{\circ} \mathrm{C}$.

2. Placentas. No tissues from patients with obstetrical complications or disturbances of carbohydrate metabolism were included in the present study. Term placentas were obtained following vaginal delivery or elective repeat Caesarian section. Retroplacental blood was expressed manually. Immediately thereafter, placental segments were excised with blunt dissection scissors, freed from adherent membranes, briefly blotted on filter paper

1 Crystalline zinc insulin (No. 499667) assaying 25 units per mg. and crystalline glucagon (No. 258-235-B54-2) were generously provided by Dr. O. K. Behrens and Dr. C. W. Pettinga of Eli Lilly Co. Somar-A (Bovine Growth Hormone), Armour No. R50109, and Panlitar (Ovine Lactogenic Hormone), Armour No. R10109, were gifts of the Endocrinology Study Section, National Institutes of Health. Thytropar (Borine Thyrotropin Armour No. R2402), Bovine Corticotropin ACTH (Armour No. R68406C) and crystalline bovine albumin (Armour), were obtained commercially. 
and frozen on solid carbon dioxide. All manipulations were completed within 5 minutes following delivery of the placenta. Weights of the placentas and membranes were measured with a single pan balance, accurate to $\pm 1 \mathrm{Gm}$. For experiments involving placental slices, the tissues were not frozen but rather wrapped in cellophane and transferred to the laboratory on cracked ice in Dewar flasks.

Obstetrical management of the patients consisted of routine premedication with 90 to $120 \mathrm{mg}$. Seconal@ and $0.4 \mathrm{mg}$. atropine. Caesarian sections were performed with spinal anesthesia. In some instances $1 \mathrm{ml}$. (10 I.U.) Pitocin (ib was administered intramuscularly prior to expulsion of the placenta. Placental enzymatic activity did not appear to be significantly affected by these medications. Comparable results were observed in two experiments in which placentas were obtained following precipitous delivery before any drugs could be administered.

\section{METHODS}

1. Slice experiments. Tissue slices of $0.5 \mathrm{~mm}$. thickness were prepared by free hand slicing, floated on chilled saline, and washed in three portions of saline to remove adherent blood. Two hundred $\pm 10 \mathrm{mg}$. slices were introduced into open $20 \mathrm{ml}$. beakers containing $2.0 \mathrm{ml}$. of modified Krebs-Ringer phosphate enriched with $2 \mathrm{mg}$. per ml. of glucose (KRP-Glucose). Following temperature equilibrations, $0.2 \mathrm{ml}$. of insulin solutions was introduced and incubation was performed in the Dubnoff apparatus in an atmosphere of 100 per cent oxygen.

2. Homogenate experiments. Weighed frozen aliquots of placenta were homogenized in Potter-Elvehjem ground-glass homogenizers with two parts $0.1 \mathrm{M}, \mathrm{pH} 7.4$, phosphate buffer to yield $1: 3$ homogenates. For the standard experimental procedure, the homogenates were centrifuged for 30 minutes in an International refrigerated centrifuge at $15,000 \times \mathrm{G}$ and $4^{\circ} \mathrm{C}$. One-half $\mathrm{ml}$. aliquots of the supernatant solutions were added to $1 \mathrm{ml}$. of $0.1 \mathrm{M}, \mathrm{pH} 7.4$, phosphate buffer contained in open 20 $\mathrm{ml}$. reaction vessels. Insulin solutions were prepared by combining diluted stock solutions of $\mathrm{I}^{131}$-insulin with varying quantities of unlabeled insulin in $0.1 \mathrm{M}, \mathrm{pH} 7.4$, sodium phosphate buffer containing $25 \mathrm{mg}$. of HSA per $\mathrm{ml}$. Enzyme and substrate preparations were equilibrated at $38^{\circ} \mathrm{C}$. Thereafter, $0.5 \mathrm{ml}$. quantities of the insulin solutions were introduced into the reaction vessels and incubation was performed at $38^{\circ} \mathrm{C}$. in the Dubnoff apparatus (shaking rate, 100 cycles per min.). Thus, the final reaction mixture in the standard experimental procedure consisted of $2 \mathrm{ml}$. of $\mathrm{pH} 7.4$ phosphate buffer containing $12.5 \mathrm{mg}$. of HSA, varying amounts of insulin, and the 15,$000 \times \mathrm{G}$ soluble supernatant solution derived from $166 \mathrm{mg}$. of wet weight placenta. Control studies had indicated that the $6.2 \mathrm{mg}$. HSA per $\mathrm{ml}$. did not alter enzymatic activity although it prevented adsorption of insulin to glassware and the spontaneous degradation of dilute iodoinsulin (vide infra). Moreover, this amount of
HSA provided sufficient carrier protein for precipitation with TCA. In all studies, concurrent incubations were performed with blank reaction vessels containing only buffer and the insulin-HSA mixtures.

3. Assay of insulin degradation. Specific techniques employed to characterize the products of insulin degradation will be discussed separately in the Results section. In the standard experimental procedure, assay was based on the solubility characteristics of the radioactivity in TCA. At timed intervals throughout incubation, $0.2 \mathrm{ml}$. aliquots of reaction mixture were removed and introduced into $13 \times 100 \mathrm{~mm}$. counting tubes containing $2 \mathrm{ml}$. of 20 per cent TCA. Radioactivity was partitioned into TCA-soluble and TCA-insoluble fractions by centrifugation. The insoluble residues were washed by resuspension in $2 \mathrm{ml}$. of 20 per cent TCA and centrifuged. The TCA supernatant fractions were pooled and the washed insoluble moieties were dissolved in $4 \mathrm{ml}$. of 30 per cent $\mathrm{KOH}$. Radioactive assay of the TCA-soluble and TCA-insoluble fractions was performed in a Nancy Wood well-type scintillation counter with a sensitivity of $1.0 \times$ $10^{\circ} \mathrm{cpm}$ per $\mu \mathrm{c}$. $\mathrm{I}^{121}$ and background of $125 \mathrm{cpm}$. Sufficient counts were observed to reduce the probable error of the measurement to less than \pm 3 per cent. After appropriate corrections for blanks, the TCA-soluble radioactivity in individual specimens (i.e., nonprecipitable $\mathrm{I}^{131}$ ) was expressed as a percentage of the total radioactivity within the system (i.e., the sum of the TCA-soluble plus TCA-insoluble radioactivity).

In the slice experiments, $2 \mathrm{ml}$. of 20 per cent TCA was added to the vessels at the end of incubation. The flask contents were quantitatively transferred to Potter-Elvehjem ground-glass homogenizers and were homogenized preparatory to fractionation into TCA-soluble and TCAinsoluble components as above.

4. Analytical techniques. Paper electrophoresis was performed with the apparatus and techniques described elsewhere (16). Butanol-acetic acid-water 78:10:12 (B Ac) and butanol-dioxane-2 $\mathrm{N} \mathrm{NH}_{3} 4: 1: 5$ (BDA) were employed for chromatography. Herein, portions of untreated reaction mixture, or TCA-soluble supernatant were applied to Whatman No. 1 filter paper after being supplemented with carrier L-thyroxine $\left(T_{4}\right)$, L-triiodothyronine $\left(\mathrm{T}_{3}\right)$, L-monoiodotyrosine (MIT), L-diiodotyrosine (DIT), sodium iodide, and $1 \times 10^{-8} \mathrm{M}$ 1-methyl-2 mercaptoimidazole. The carrier compounds were localized by successively spraying with solutions of 0.1 per cent palladium chloride and diazotized sulfanilic acid. Duplicate chromatograms were also sprayed with - 0.1 per cent ninhydrin in acetone. Distribution of radioactivity in individual electrophoretograms and chromatograms was qualitatively localized by radioautography and quantified with the use of an electronically integrating, automatically recording, strip-scanner developed in this laboratory (17). A micro-Kjeldahl method was employed for analysis of total nitrogen in duplicate aliquots of placental extracts. Blood glucose was measured by the method of Somogyi as modified by Nelson (18). 
RESULTS

\section{Methods}

The published findings of others (19-22) prompted a re-examination of the potential methodological artifacts in the use of $\mathrm{I}^{131}$-insulin in in vitro systems. Representative experiments are described in detail below.

A. Adsorption to glassware. Ten uncovered 20 $\mathrm{ml}$. beakers were filled with constant tracer quantities of $I^{131}$-insulin, varying amounts of crystalline unlabeled insulin, and sufficient $0.1 \mathrm{M}, \mathrm{pH} 7.4$, phosphate buffer to yield $2.0 \mathrm{ml}$. systems containing 0.25 to $500.25 \mu \mathrm{g}$. insulin per ml. (Table I). The vessels were counted by being placed on a fixed aluminum disk directly above a scintillation detector head. Thereafter, they were incubated for 30 minutes at $38^{\circ} \mathrm{C}$. in the Dubnoff apparatus. Following incubation, the beakers were emptied into separate $10 \mathrm{ml}$. volumetric flasks containing $50 \mathrm{mg}$. HSA and refilled with $2.0 \mathrm{ml}$. of phosphate buffer. Repeat radioactive assay was performed to assess the "percentage of the initial radioactivity" which had been retained within each beaker ("glassware adsorption"). This exceeded 25 per cent of the initial counts in the vessels which originally did not contain more than $2.5 \mu \mathrm{g}$. insulin per ml. (Column A, Table I). The ease with which

TABLE I

Adsorption of insulin to glassware and spontaneous degradation of insulin during incubation in aqueous media

Reaction mixture: $2 \mathrm{ml}$. $\mathrm{pH} 7.4$ phosphate buffer containing 0.25 to $500.25 \mu g$. insulin per ml. and no other protein. Incubation: 30 minutes, $38^{\circ} \mathrm{C}$.

\begin{tabular}{rrcccc} 
No. & Insulin & HSA & A* & B十 & C \\
\hline & Mg./ml. & mg./ml. & $\%$ & $\%$ & $\%$ \\
1 & 0.25 & 0 & 46.7 & 19.6 & 8.9 \\
2 & 0.75 & 0 & 48.7 & 13.8 & 7.9 \\
3 & 1.50 & 0 & 32.9 & 7.7 & 6.0 \\
4 & 2.50 & 0 & 27.6 & 6.4 & 4.4 \\
5 & 5.00 & 0 & 15.3 & 3.8 & 3.9 \\
6 & 10.25 & 0 & 8.5 & 2.3 & 1.2 \\
7 & 50.25 & 0 & 4.8 & 1.4 & 0.7 \\
8 & 100.25 & 0 & 3.5 & 0.7 & 0 \\
9 & 200.25 & 0 & 3.1 & 0.5 & 0 \\
10 & 500.25 & 0 & 3.9 & 0.6 & 0
\end{tabular}

* A : "per cent of initial radioactivity" retained in beaker after decanting the original $2.0 \mathrm{ml}$. suspending medium (i.e., "glassware adsorption").

† B : "per cent of initial radioactivity" retained in beaker after washing successively with $2.0 \mathrm{ml}$. and $3.0 \mathrm{ml}$. of phosphate buffer.

$\ddagger$ C: minimal estimate of "per cent of initial radioactivity" rendered soluble in TCA during incubation (i.e., "spontaneous degradation"). the "adsorbed" radioactivity could be removed by washing was assessed as follows: beakers were decanted into the same volumetric flasks; a single washing with $3.0 \mathrm{ml}$. of phosphate buffer was performed; then the beakers were counted for a third time. As shown in Column B, Table I, more than 5 per cent of the initial radioactivity still remained in these beakers.

B. Spontaneous degradation. The albumin-containing $10 \mathrm{ml}$. volumetric flasks into which the insulin and the beaker washings had been decanted in the above experiments were employed to assess spontaneous degradation. Control volumetric flasks were prepared by directly combining 0.50 $\mu \mathrm{g}$. $\mathrm{I}^{131}$-insulin with $50 \mathrm{mg}$. HSA without preliminary incubation. Flasks were diluted to constant volume and duplicate $1.0 \mathrm{ml}$. aliquots from each were fractionated into TCA-soluble and TCAinsoluble components. After appropriate correction for TCA-soluble radioactivity in control flasks, minimal estimate of spontaneous degradation during incubation was obtained by multiplying $a$ ) the percentage of the initial radioactivity which had been transferred to the volumetric flasks (i.e., 100 per cent minus Column B, Table I) by $b$ ) the percentage of the radioactivity in the volumetric flasks which was soluble in TCA. Results are listed in Column C, Table I. During aerobic incubation of aqueous systems containing less than $2.5 \mu \mathrm{g}$. insulin per ml., more than 5 per cent of the insulin is rendered soluble in TCA.

Similar values for glassware adsorption and spontaneous degradation were obtained in repeat studies with varying proportions of $\mathrm{I}^{131}$-labeled and crystalline unlabeled insulin. Thus, the phenomena seem to reflect the fate of all of the insulin within the system rather than merely the labeled material. However, some adsorptive peculiarities of the $\mathrm{I}^{131}$-insulin due to modification of the phenolic hydroxyl in the iodinated tyrosyl groups cannot be wholly excluded.

C. Effects of human serum albumin on adsorption to glassware and spontaneous degradation. Similar protocols were employed to assess the effects of HSA upon the adsorption to glassware and spontaneous degradation of dilute insulin solutions. For these studies, open $20 \mathrm{ml}$. beakers were filled with $2.0 \mathrm{ml}$. of phosphate buffer $(\mathrm{pH} 7.4)$ containing constant amounts of labeled and unlabeled insulin $(0.25 \mu \mathrm{g}$. insulin per $\mathrm{ml}$.) and 
TABLE II

Effect of human serum albumin upon adsorption of insulin to glassware and spontaneous degradation of insulin during incubation in aqueous media

Reaction mixture: $2.0 \mathrm{ml}$. $\mathrm{pH} 7.4$ phosphate buffer containing $0.25 \mu \mathrm{g}$ insulin and 0 to $10.0 \mathrm{mg}$. HSA per $\mathrm{ml}$. Incubation: 30 minutes, $38^{\circ} \mathrm{C}$.

\begin{tabular}{|c|c|c|c|c|c|}
\hline No. & Insulin & HSA & $A^{*}$ & B* & $\mathrm{C}^{*}$ \\
\hline & $\mu g . / m l$. & $m g . / m l$ & & & \\
\hline 1 & 0.25 & 0 & 46.8 & 21.1 & 5.3 \\
\hline 2 & 0.25 & 0.05 & 16.3 & 6.4 & 2.0 \\
\hline 3 & 0.25 & 0.10 & 8.7 & 2.3 & 0 \\
\hline 4 & 0.25 & 0.20 & 7.9 & 2.1 & 0 \\
\hline 5 & 0.25 & 0.50 & 6.1 & 1.6 & 0 \\
\hline 6 & 0.25 & 1.00 & 5.9 & 1.6 & 0 \\
\hline 7 & 0.25 & 2.00 & 6.2 & 1.4 & 0 \\
\hline 8 & 0.25 & 5.00 & 4.3 & 0.8 & 0 \\
\hline 9 & 0.25 & 10.00 & 4.4 & 0.7 & 0 \\
\hline
\end{tabular}

*As in Table I.

varying anounts of HSA (0 to $10.0 \mathrm{mg}$. per ml.) (Table II). After 30 minutes of incubation of these beakers, the adsorption of radioactivity to glassware in vessels containing no HSA averaged 46.8 per cent as above (Table II, Column A). However, with as little as $0.10 \mathrm{mg}$. HSA per $\mathrm{ml}$. in the suspending media, this adsorption was reduced to below 10 per cent. Moreover, when the initial suspending medium contained $0.50 \mathrm{mg}$. HSA per ml., two aqueous washings sufficed to recover more than 98 per cent of the radioactivity (Table II, Column B). Finally, the spontaneous degradation of insulin during 30 minutes of aerobic incubation did not occur in media containing $0.10 \mathrm{mg}$. HSA per $\mathrm{ml}$. (Table II, Column C).

Additional studies were performed to evaluate the reversibility of glassware adsorption. More than half of the insulin adsorbed to glass during 30 minutes of incubation of aqueous media containing $0.25 \mu \mathrm{g}$. insulin per $\mathrm{ml}$. could be recovered by introducing $25 \mathrm{mg}$. HSA into the system for 5 minutes prior to decanting.

Experiments to be published elsewhere would indicate that HSA does not contain insulin, and that the effects of HSA are not due to an interaction between HSA and insulin. Rather, at $\mathrm{pH} 7.4$, insulin and HSA seem to compete for similar binding sites on the glass surface.

D. Conclusions. Significant adsorption to glassware and spontaneous degradation of insulin may occur during incubation of dilute insulin solutions in open vessels. The proportional magnitude of the phenomena at $\mathrm{pH} 7.4$ is conditioned by $a$ ) the concentration of insulin, $b$ ) the presence of other negatively charged proteins, such as HSA, and $c$ ) the relationship between surface area and volume of medium. The contribution of such methodological artifacts can be minimized by the inclusion of HSA in all suspending media."

\section{Degradation of insulin by placental structures}

Placental structures were prepared in various ways to assess their capacity to degrade insulin into TCA-soluble products.

A. Comparison of slices versus homogenates. Results of one of three experiments are presented in Table III. Slices of chorion, amnion, and placenta $(200 \pm 10 \mathrm{mg}$. wet weight), and $0.2 \mathrm{ml}$. aliquots of maternal or cord blood were incubated in $2 \mathrm{ml}$. KRP-Glucose containing unlabeled insulin and tracer quantities of $\mathrm{I}^{131}$-insulin. Cell-free systems were prepared by homogenizing $1.0 \mathrm{Gm}$. of slices or $1 \mathrm{ml}$. of maternal or cord blood with $4 \mathrm{ml}$. of KRP-Glucose and then incubating $1 \mathrm{ml}$. aliquots of the homogenates with the same amount of insulin in a final volume of $2.2 \mathrm{ml}$. During 60 minutes of incubation, all of the slice systems liberated appreciable quantities of "nonprecipitable I ${ }^{131}$ " (Table III). Placental slices were most active on the basis of wet weight. However, none of the slice preparations was as active as homogenates prepared from equivalent amounts of tissue

TABLE III

The degradation of insulin by placental structures

\begin{tabular}{|c|c|c|}
\hline $\begin{array}{l}\text { Reaction mixture: KRP-Glucose } \\
\text { preparation or } 1 \mathrm{ml} \text { of } 1: 5 \\
\text { tration } 25.02 \mu \mathrm{g} \text {. per ml. I }\end{array}$ & $\begin{array}{l}\text { I } 7.4 \mathrm{pl} \\
\text { logenat } \\
\text { ation: }\end{array}$ & $\begin{array}{l}0 \pm 10 \mathrm{mg} \text {. } \mathrm{c} \\
\text { inal insulin } \mathrm{cc} \\
\text { inutes, } 38^{\circ} \mathrm{C}\end{array}$ \\
\hline detalls, see text. & Nor & $\begin{array}{l}\text { ipitable I }{ }^{131} \\
\text { total I I }\end{array}$ \\
\hline & Slices & Homogenate \\
\hline Tissue: & & \\
\hline Chorion & 11.5 & 57.1 \\
\hline Amnion & 10.6 & 51.3 \\
\hline Placenta & 36.6 & 67.5 \\
\hline Maternal blood & 1.3 & 0.1 \\
\hline Cord blood & 0.5 & 0.1 \\
\hline
\end{tabular}

${ }^{2}$ Many other proteins are equally effective. However, the concentrations of HSA which prevent adsorption to glassware and spontaneous degradation do not affect enzymatic proteolysis of insulin whereas some of the other proteins, such as Cohn Fractions III and IV-1, contain noncompetitive inhibitors of insulin-degrading enzymes (23). 


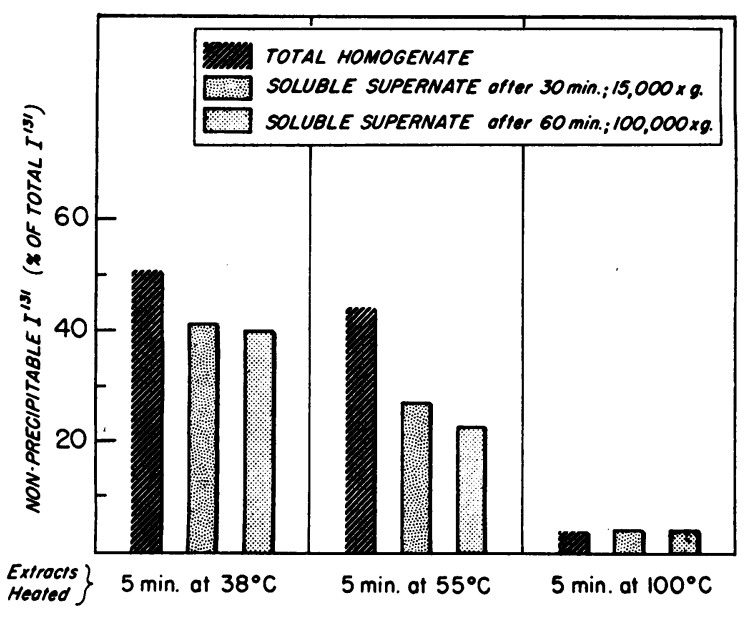

Fig. 1. Insulin Degradation by Subcellular Fractions of Human Placenta: Thermal Lability of Subcellular Fractions

Placental fractions were prepared as outlined in text and heated for five minutes at $38^{\circ}, 55^{\circ}$ or $100^{\circ} \mathrm{C}$. prior to incubation. Nitrogen contents of the $1: 3$ total homogenate, $15,000 \times G$ and $100,000 \times G$ soluble supernatants were $689.7,455.6$, and $336.4 \mathrm{mg}$. per $100 \mathrm{ml}$., respectively. Incubation: 30 minutes, $38^{\circ} \mathrm{C}$. Insulin content of reaction mixture: $50.01 \mu \mathrm{g}$. per $\mathrm{ml}$.

(Table III). The findings cannot be attributed to occluded blood since negligible degradation was effected by maternal or cord blood.

B. Subcellular localization of placental activity. A portion of a 1:3 placental homogenate was stored at $4^{\circ} \mathrm{C}$. while other aliquots were centrifuged either in $a$ ) an International Refrigerated centrifuge at $4^{\circ} \mathrm{C}$., $15,000 \times \mathrm{G}$ for 30 minutes to sediment cellular debris, nuclei and most mitochondria or in $b$ ) a Model L Spinco preparative ultracentrifuge at $4^{\circ} \mathrm{C}$., $100,000 \times \mathrm{G}$ for $60 \mathrm{~min}$ utes to sediment most of the microsomes in addition to the denser subcellular components. Portions of intact homogenate and the two supernatant solutions were heated for 5 minutes in water baths at $38^{\circ}, 55^{\circ}$ and $100^{\circ} \mathrm{C}$. Thereafter, $0.5 \mathrm{ml}$. aliquots of the various heated and unheated preparations were incubated for 30 minutes at $38^{\circ} \mathrm{C}$. with $1.5 \mathrm{ml}$. of insulin-containing phosphate buffer. As shown in Figure 1, most of the insulin-degrading capacity of human placenta was localized in the soluble cytoplasm which remained after centrifugation at $100,000 \times$ G. Specific activity expressed as "per cent nonprecipitable $\mathrm{I}^{131}$ per mg. N of placental extract" was increased 60 to
200 per cent by such centrifugation. The activity was largely, although not entirely, destroyed by 5 minutes of boiling.

C. Conclusions. Human placenta contains heatstable and heat-labile systems for liberating TCAsoluble radioactivity from $\mathrm{I}^{131}$-insulin. Activity is maximal in cell-free systems and localized principally in the nonparticulate soluble cytoplasm.

\section{Products of insulin degradation by placental extracts}

Additional techniques were employed to characterize the products of the reaction between insulin and placental extracts. For these and for all subsequent studies, placental homogenates were prepared and incubation was performed according to the standard experimental procedure.

$A$. Paper electrophoresis. In dilute solution, $\mathrm{I}^{131}$-insulin remains bound at the origin during paper electrophoresis in veronal buffer at $\mathrm{pH} 8.6$ (14, 21, 24). However, paper electrophoresis of the reaction mixture following incubation of $\mathrm{I}^{\mathbf{1 3 1}_{-}}$ insulin and placental extract disclosed radioactive products which migrated in the areas corresponding to the slowest moving portion of albumin and the $\alpha_{2}$-globulins (Figure 2). In addition, occasionally a small amount of radioactivity was noted in the prealbumin area. More than 90 per cent of the applied radioactivity could be accounted for in these areas. Under similar conditions, recovery of inorganic $\mathrm{I}^{131}$ averages 3.1 per cent (16). When multiple reaction vessels were prepared with constant tracer quantities of $\mathrm{I}^{131}$-insulin and varying amounts of crystalline unlabeled insulin, the formation of radioactive degradation products was inversely proportional to the total amount of insulin within the system (Figure 2). Although the characteristic electrophoretic migration at $\mathrm{pH}$ 8.6 of the radioactive degradation products may have resulted in part from associations with plasma proteins, a similar migration was exhibited during electrophoresis of the supernatant solutions obtained following TCA-precipitation of the reaction mixtures.

B. Paper chromatography. In both acid (BAc) and alkaline (BDA) solvents, the radioactivity in the reaction mixture at all intervals following incubation was apportioned between the origin and areas which corresponded to the migration of the 


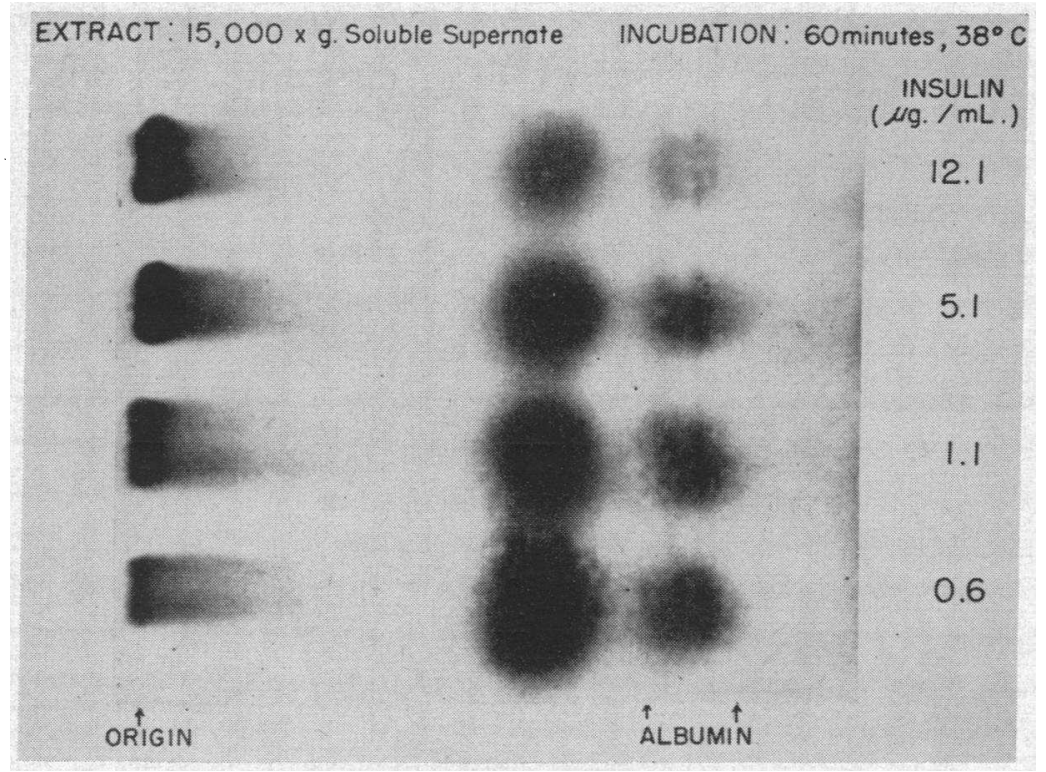

Fig. 2. Electrophoretic Migration of Products of I ${ }^{181}$-Insulin Degradation by Placental Extract

Standard $15,000 \times \mathrm{G}$ placental extract was diluted fivefold with $\mathrm{pH} 7.4$ phosphate buffer to yield the equivalent of $16.6 \mathrm{mg}$. wet weight placenta per $\mathrm{ml}$. final reaction mixture. Final insulin concentration was as indicated in illustration. Incubation: 60 minutes, $38^{\circ} \mathrm{C}$. Reaction mixture directly applied for paper electrophoresis at end of incubation. Electrophoresis was performed at $4^{\circ} \mathrm{C}$. to minimize further activity of the dilute enzyme preparation. Radioautograph of electrophoretograms is depicted above.

MIT and DIT markers (Figure 3). The ratios of "MIT-like" "DIT-like" radioactivity ranged from 3.0 to 4.5 with four preparations of $\mathrm{I}^{131}$-insulin. Negligible radioactivity was observed in the zones corresponding to ionic iodide. Further characterization of the radioactive products was not attempted since it is not germane to the present studies. Thus, whether the "MIT- and DIT-like" components consist entirely of iodinated tyrosines (and do not include peptides of similar mobilities), and whether all of the "origin" radioactivity represents unaltered $\mathrm{I}^{131}$-insulin cannot be said with certainty. However, from the data, simple deiodination may be excluded as the basis for the manifest placental activity. Since the absolute formation of radioactive "MIT- and DIT-like" products was reduced by the inclusion of increasing quantities of unlabeled insulin in the reaction mixtures (Figure 3 ), it was inferred that the $\mathrm{I}^{131}$-insulin validly mirrored the proteolysis of unlabeled insulin.

C. Liberation of TCA-soluble products of op- tical density at $280 m \mu$. Documentation of proteolysis of unlabeled insulin was secured by the method of Tomizawa and Williams (25). Homogenates were prepared by the standard experimental procedure and dialyzed for 18 hours at $4^{\circ}$ C. against repeated changes of $0.1 \mathrm{M}$ phosphate buffer, $\mathrm{pH}$ 7.4. Thereafter, $1 \mathrm{ml}$. aliquots were incubated with $1 \mathrm{ml}$. of $a$ ) phosphate buffer or $b$ ) phosphate buffer containing $2 \mathrm{mg}$. crystalline insulin per $\mathrm{ml}$. Control vessels containing phosphate buffer alone or phosphate buffer plus insulin were similarly incubated. At various times during incubation, the contents of the beakers were quantitatively decanted into $3 \mathrm{ml}$. of chilled 10 per cent TCA, and the TCA-soluble supernatant solutions were read in a Beckman DU spectrophotometer at $280 \mathrm{~m} \mu$. Significant evolution of TCAsoluble, ultraviolet-absorbing moieties was only observed in systems containing both insulin and placental extract (Table IV).

The preliminary dialysis in these studies was instituted to reduce the appreciable concentration 


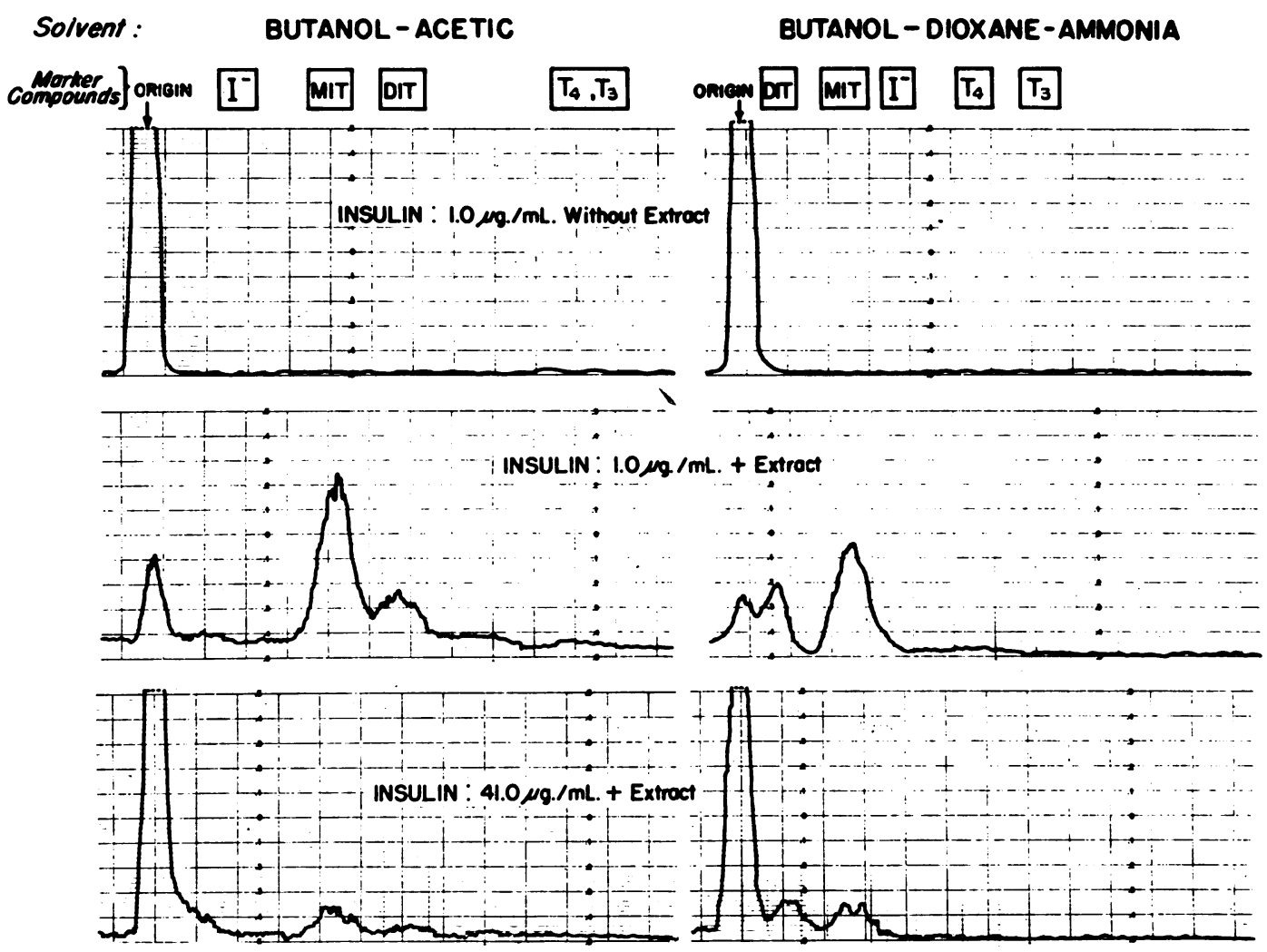

Fig. 3. Chromatography of Products of ${ }^{131}$-Insulin Degradation by Placental Extract

Reaction mixture: $2 \mathrm{ml}$. pH 7.4 phosphate buffer containing 15,000 $\times$ G placental extract as in standard experimental procedure. Incubation: 30 minutes, $38^{\circ} \mathrm{C}$. At end of incubation, aliquot of reaction mixture was applied to Whatman No. 1 filter paper, supplemented with carrier compounds, dried and chromatographed as indicated in text. Radioactive scans of chromatograms are illustrated above.

of nonprecipitable components of optical density at $280 \mathrm{~m} \mu$ in the placental extracts. However, such dialysis also diminishes the insulin-degrading capacity of placental preparations.

TABLE IV

Liberation of TCA-soluble products of optical density at $280 \mathrm{m \mu}$.

\begin{tabular}{|c|c|c|c|}
\hline \multirow[b]{2}{*}{ Phosphate buffer plus } & \multicolumn{3}{|c|}{ Optical density at $280 \mathrm{~m} \mu^{*}$} \\
\hline & $\begin{array}{c}0 \mathrm{~min} . \\
\text { incuba- } \\
\text { tion }\end{array}$ & $\begin{array}{l}30 \mathrm{~min} . \\
\text { incuba- } \\
\text { tion }\end{array}$ & $\begin{array}{c}60 \mathrm{~min} \\
\text { incuba } \\
\text { tion }\end{array}$ \\
\hline ho & 5 & 0.0 & 0.072 \\
\hline isul & 0.080 & 0.075 & 0.078 \\
\hline Placental e & 0.330 & 0.334 & 0.350 \\
\hline ulin plus placental extract & 0.328 & 0.410 & 0.535 \\
\hline
\end{tabular}

* Reaction mixture was decanted into TCA; optical density of TCA supernatant was determined.
D. Bioassay. Alteration in the biological potency of insulin incubated with placental extracts was assessed by injecting portions of control and reaction mixtures into the ear veins of fasted 2 to $3 \mathrm{Kg}$. rabbits. Timed blood specimens for glucose analysis were obtained from the vessels of the ear or by cardiac puncture. Each solution was assayed in a separate animal. One of four experiments is presented in Table V. Insulin which had been incubated for 30 minutes with placental extract did not produce the same degree of hypoglycemia as insulin which had been incubated for a comparable period of time but without placental extract. The placental extracts per se effected negligible changes in blood sugar levels.

E. Conclusions. The electrophoretic, chromatographic and spectrophotometric studies demon- 
TABLE V

Inactivation of insulin by placental extracts

Reaction mixture: $2.0 \mathrm{ml}$, pH 7.4 phosphate buffer containing 15,000 $\times \mathrm{G}$ placental extract as in standard experimental procedure and $60 \mathrm{~g}$. (1.5 units) insulin per ml. Control vessels containing placental extract without insulin, and $b$ ) insulin withoutaining a) extract, were incubated concurrently. Incubation: 30 minutes, $38^{\circ} \mathrm{C}$.

Assay: Rabbits were injected with $1.0 \mathrm{ml}$. of reaction mixture at end of incubation.

\begin{tabular}{lcc}
\multicolumn{1}{c}{ Reaction mixture } & \multicolumn{2}{c}{ Minutes after injection } \\
& (\% of initial blood sugar) \\
\hline & $30 \mathrm{~min}$. & $60 \mathrm{~min}$. \\
Phosphate buffer plus insulin & 42.4 & 56.8 \\
Phosphate buffer plus placental & 95.1 & 98.9 \\
$\begin{array}{l}\text { extract } \\
\text { Placental extract plus insulin }\end{array}$ & 62.1 & 80.1
\end{tabular}

strate that the formation of TCA-soluble radioactivity from $\mathrm{I}^{131}$-insulin by placental extracts represents proteolysis of the insulin molecule. The biological consequence of this proteolysis is evidenced by a reduction in the hypoglycemic potency of the insulin.

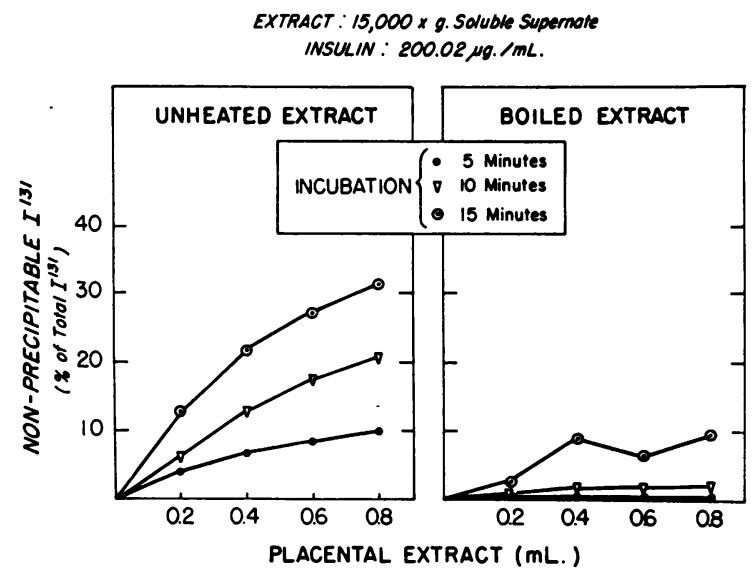

Fig. 4. Relationship Between Quantity of Placental Extract and Insulin Degradation

$15,000 \times \mathrm{G}$ placental extract was prepared as in standard experimental procedure. Various quantities of unheated and boiled extract were incubated for 5,10 or 15 minutes in a reaction mixture consisting of $2.0 \mathrm{ml}$. volume and containing $200.02 \mu \mathrm{g}$. insulin per $\mathrm{ml}$.

EXTRACT : 15,000 $\times$ g. Soluble Supernate

PH : 7.4 TEMP. : $38^{\circ} \mathrm{C}$

REACTION MIXTURE: EXtroct from $0.083 \mathrm{gm}$. Plocento /mL.
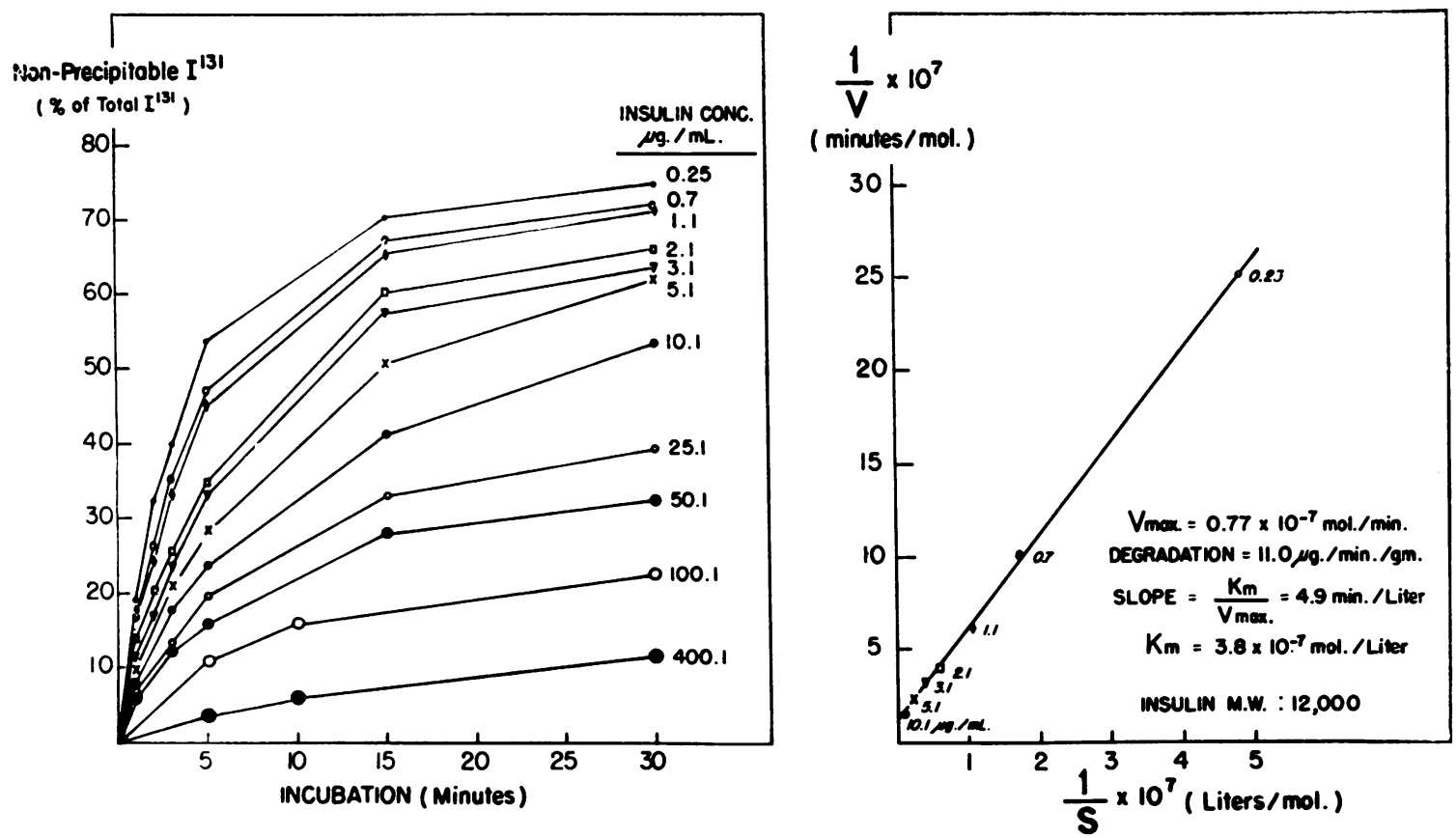

Fig. 5. Kinetics of Insulin Degradation by Placental Extracts

Reaction mixture: $2 \mathrm{ml}$. pH 7.4 phosphate buffer containing various quantities of insulin and $15,000 \times \mathrm{G}$ placental extract was prepared as in standard experimental procedure. Aliquots of reaction mixtures were removed at various intervals during incubation. Nitrogen content of the $1: 315,000 \times \mathrm{G}$ placental extract employed for this study was $408.2 \mathrm{mg}$. per $100 \mathrm{ml}$. 
4. Characterization of the insulin-degrading systems of human placenta

Although the $15,000 \times G$ soluble supernatant fraction derived from human placentas does not represent a purified preparation, its activity was assessed by various conventional techniques of enzymology.

A. Relationship between insulin degradation and quantity of placental extract. Constant amounts of insulin were incubated with varying amounts of the $15,000 \times \mathrm{G}$ placental extract. A representative experiment is illustrated in Figure 4. The formation of nonprecipitable $\mathrm{I}^{131}$ during incubation of $\mathrm{I}^{131}$-insulin was directly correlated with the quantity of extract in the reaction mixture. Such a relationship did not obtain with extract which had been boiled for 5 minutes prior to incubation.

B. Kinetics. The left-hand portion of Figure 5 represents the fraction of $\mathrm{I}^{131}$-insulin degraded as a function of time in the standard experimental procedure. Prolonged linear degradation was not observed at any substrate concentration. Thus, for kinetic analysis, the initial velocity

TABLE VI

Thermal inactivation of the insulin-degrading capacity of placental extracts

\begin{tabular}{|c|c|c|c|c|c|}
\hline \multicolumn{6}{|c|}{ 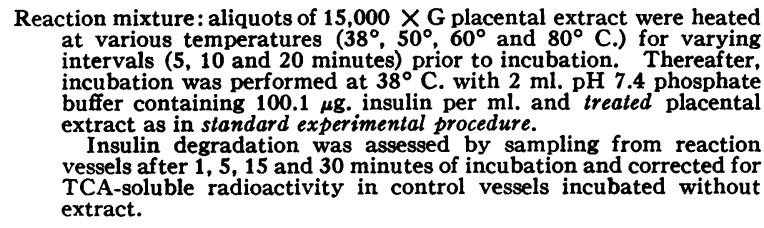 } \\
\hline \multicolumn{2}{|c|}{$\begin{array}{l}\text { Preincubation } \\
\text { heating of } \\
\text { extract }\end{array}$} & \multicolumn{4}{|c|}{$\begin{array}{l}\text { Nonprecipitable } I^{131}(\%) \text { formed } \\
\text { during incubation of extract for: }\end{array}$} \\
\hline Temp. & $\underset{\text { Dion }}{\text { Dura- }}$ & $\min$. & $\underset{\min }{5}$ & $\begin{array}{c}15 \\
\text { min. }\end{array}$ & $\begin{array}{c}30 \\
\text { min. }\end{array}$ \\
\hline $\begin{array}{l}{ }^{\circ} \mathrm{C} . \\
38\end{array}$ & $\begin{array}{r}\text { min. } \\
5 \\
10 \\
20\end{array}$ & $\begin{array}{l}7.2 \\
7.4 \\
6.8\end{array}$ & $\begin{array}{l}14.6 \\
12.9 \\
11.2\end{array}$ & $\begin{array}{l}15.1 \\
15.8 \\
15.0\end{array}$ & $\begin{array}{l}22.9 \\
21.8 \\
22.2\end{array}$ \\
\hline 50 & $\begin{array}{r}5 \\
10 \\
20\end{array}$ & $\begin{array}{l}6.1 \\
5.6 \\
4.4\end{array}$ & $\begin{array}{r}11.3 \\
11.1 \\
8.7\end{array}$ & $\begin{array}{l}14.5 \\
13.2 \\
10.8\end{array}$ & $\begin{array}{l}21.6 \\
22.1 \\
18.2\end{array}$ \\
\hline 60 & $\begin{array}{r}5 \\
10 \\
20\end{array}$ & $\begin{array}{l}7.8 \\
3.3 \\
3.2\end{array}$ & $\begin{array}{l}7.8 \\
6.1 \\
3.9\end{array}$ & $\begin{array}{l}9.1 \\
7.5 \\
7.2\end{array}$ & $\begin{array}{r}14.4 \\
12.9 \\
8.9\end{array}$ \\
\hline 80 & $\begin{array}{r}5 \\
10 \\
20\end{array}$ & 0.7 & $\begin{array}{l}2.9 \\
1.6\end{array}$ & $\begin{array}{l}3.5 \\
3.4 \\
3.6\end{array}$ & $\begin{array}{l}6.7 \\
7.0 \\
6.2\end{array}$ \\
\hline
\end{tabular}

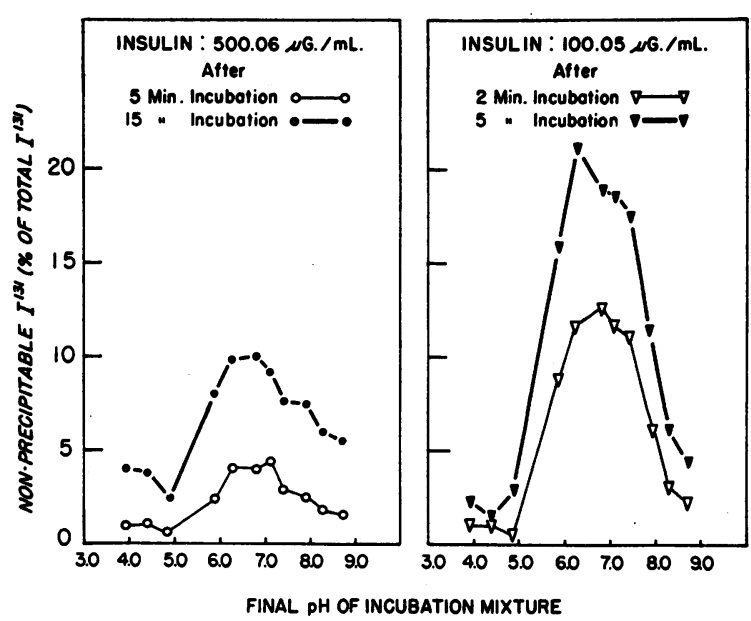

Fig. 6. The Effect of pH on Insulin Degradation by Placental Extract

Reaction mixture containing $2 \mathrm{ml}$. volume and $15,000 \times$ $G$ placental extract as in standard experimental procedure. Acetate buffer employed for $\mathrm{pH} 3.5$ to 4.5 ; phosphate buffer for $\mathrm{pH} 5.4$ to 8.1 ; and Tris (hydroxymethyl) aminomethane buffer for $\mathrm{pH} 8.2$ to 9.0 The $\mathrm{pH}$ values of the reaction mixtures before and after 15 minutes of incubation were: $3.50,3.97 ; 4.00,4.40 ; 4.57,4.87 ; 5.41,5.91$; $6.00,6.23 ; 6.65,6.84 ; 7.00,7.15 ; 7.40,7.42 ; 8.10,7.91$; $8.20,8.27$; and $9.00,8.71$.

at each concentration was determined as the product of the initial insulin concentration and the zero time slope. A Lineweaver-Burk plot of the values obtained during the first minute at the lowest concentrations of insulin is presented in the right-hand portion of Figure 5. During this interval, degradation of insulin by boiled placental extracts is negligible and correction for the thermostable activity does not affect the values significantly. On the basis of a molecular weight of 12,000 for insulin, the Michaelis-Menten constant $(\mathrm{Km})$ for the thermo-labile reaction is $3.8 \times 10^{-7}$ Moles per L. and $\mathrm{V}_{\max }$ is $0.77 \times 10^{-7}$ Moles per minute. Correction for the dilution in the standard experimental procedure yields a $\mathrm{V}_{\max }$ of $11 \mu \mathrm{g}$. per minute per $\mathrm{Gm}$. of wet weight of placenta.

C. Stability. Placental extracts were heated for various intervals at $38^{\circ}, 50^{\circ}, 60^{\circ}$ and $80^{\circ} \mathrm{C}$. and assayed for residual activity. As shown on Table VI, about one-fourth of the insulin-degrading capacity which was observed during 15 to 30 minutes of incubation remained, even after 20 minutes of heating at $80^{\circ} \mathrm{C}$.

The thermo-labile enzymatic activity was re- 
duced by storing $15,000 \times \mathrm{G}$ placental extracts at $-18^{\circ} \mathrm{C}$. for prolonged periods. Kinetic analysis indicated that this resulted from a diminution of $\mathrm{V}_{\max }$ without a significant change in $\mathrm{Km}$. The thermo-stable activity was not reduced by storage of frozen placental extracts.

D. Effect of $p H$ and temperature. The relationship between $\mathrm{pH}$ and enzymatic activity is shown in Figure 6. Experiments were conducted with short incubation to minimize the contributions of the relatively slow, thermo-stable component. At all insulin concentrations, insulin degradation was maximal between $\mathrm{pH} 6.5$ and 7.0.

The relationship between insulin degradation and temperature of incubation is demonstrated in the experiment presented in Table VII. During 5 minutes of incubation, the mean temperature velocity constant was $22,000 \mathrm{cal}$. per Mole for the range $24^{\circ}$ to $34^{\circ} \mathrm{C}$. and 9,000 cal. per Mole for $34^{\circ}$ to $38^{\circ} \mathrm{C}$. Reaction velocity declined at temperatures between $42^{\circ}$ and $55^{\circ} \mathrm{C}$.

E. Inhibition of enzymatic activity. Enzyme inhibitors previously assessed in the "insulinase" system of rat liver $(10,12,26)$ were examined with placental extracts (Table VIII). Profound inhibition was effected with reagents which may affect sulfhydryl groups by oxidation-reduction (cf., cupric salts), alkylation (cf., iodoacetate), or mercaptide formation (cf., p-chloromercuribenzoate).

Specificity of the placental system was assessed by incubating small quantities of insulin $\left(5 \times 10^{-7}\right.$

TABLE VII

Insulin degradation by placental extracts at various temperatures of incubation

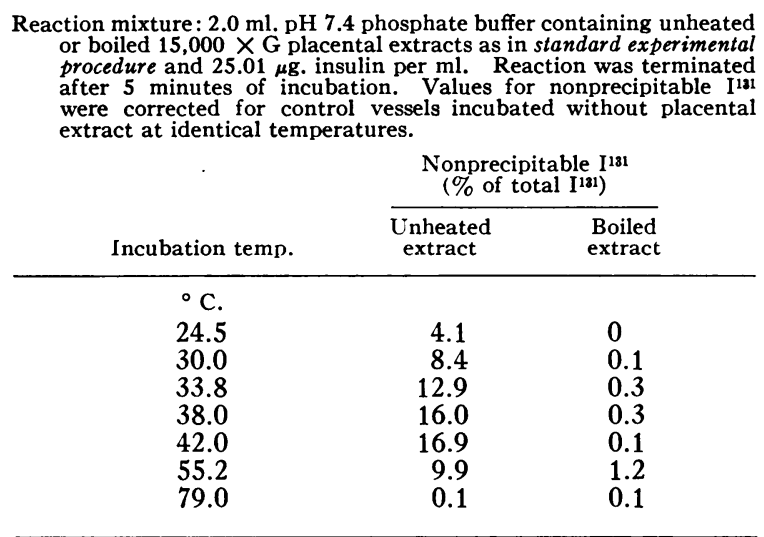

TABLE VIII

The effect of enzyme inhibitors on insulin degradation by placental extracts

Reaction mixture: $2 \mathrm{ml}$. pH 7.4 phosphate buffer containing $100.03 \mu \mathrm{g}$ insulin per ml., 15,000 $\times \mathrm{G}$ placental extract as in standard experimental procedure \pm enzyme inhibitor. Incubation: 30 minutes, $38^{\circ} \mathrm{C}$.

\begin{tabular}{lcc}
\multicolumn{1}{c}{ Inhibitor } & $\begin{array}{c}\text { Concentration } \\
\left(\times 10^{-3} \mathrm{M}\right)\end{array}$ & $\begin{array}{c}\text { Nonprecipi- } \\
\text { table } \mathrm{I}^{131} \\
\left(\% \text { of total } \mathrm{I}^{131}\right)\end{array}$ \\
\hline None & & 31.8 \\
p-Chloromercuribenzoate & 0.5 & 2.9 \\
Cupric sulfate & 0.5 & 5.4 \\
Zinc sulfate & 0.5 & 25.1 \\
Iodoacetic acid & 1.0 & 18.8 \\
Sodium azide & 1.0 & 30.3 \\
Sodium arsenite & 1.0 & 27.3 \\
\hline
\end{tabular}

$\mathrm{M})^{3}$ in the presence of $1 \times 10^{-6}$ to $1 \times 10^{-5} \mathrm{M}^{3}$ concentrations of crystalline bovine serum albumin, ${ }^{1}$ or protein hormones such as glucagon, ${ }^{1}$ corticotropin (ACTH) ${ }^{1}$ thyrotropin ( TSH $),{ }^{1}$ somatotropin $(\mathrm{STH}),{ }^{1}$ and lactogenic hormone $(\mathrm{LTH}) .{ }^{1} \quad$ Reactions were terminated after 5 minutes of incubation to minimize the inhibitory potential of products of proteolysis. At concentrations of $1 \times 10^{-6} \mathrm{M}$, none of the proteins appreciably altered the degradation of insulin (Figure 7 ). When present in 20 -fold excess, the protein hormones effected a modest reduction in the rate of insulin breakdown. This was most pronounced with ACTH (Figure 7). Unlabeled insulin, added to a final insulin concentration of $1 \times 10^{-6}$ to $1 \times 10^{-5} \mathrm{M}$, more effectively reduced the formation of nonprecipitable $\mathrm{I}^{131}$ than any other protein (Figure 7).

Despite the relatively small effects of the protein hormones, the potential physiological significance of the interrelationships prompted further examination of the inhibition. Results of such studies with glucagon and $\mathrm{ACTH}$ are shown in Figure 8. During 30 minutes of incubation at multiple concentrations, the effects of $\mathrm{ACTH}$ and glucagon conformed to a competitive type of inhibition.

F. Conclusions. The rapid degradation of insulin by unboiled placental extracts exhibits the lability, kinetic characteristics, thermal relation-

${ }^{3}$ Calculations of molar concentrations were based on the following values for molecular weight: insulin, 12,000; bovine serum albumin, 70,000; glucagon, 4,200; corticotropin, 4,000; thyrotropin, 10,000; somatotropin, 44,250 : and lactogenic hormone, 32,000 . 


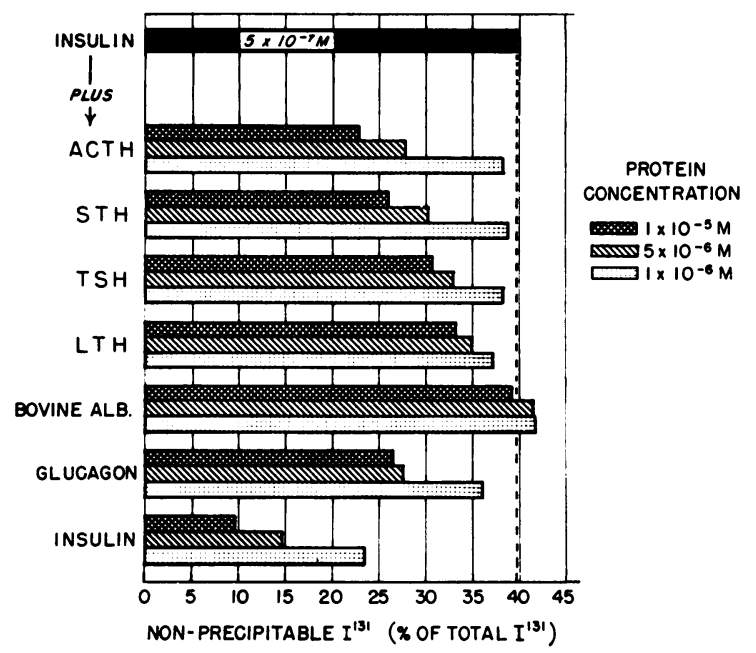

Fig. 7. The Effect of Various Proteins on Insulin Degradation by Placental Extracts

Incubation: 5 minutes, $38^{\circ} \mathrm{C}$. For details see text.

ships and circumscribed $\mathrm{pH}$ dependencies that are typical of enzymatic reactions. Moreover, the activity is impaired by sulfhydryl reagents and may be competitively inhibited in the presence of large quantities of such protein hormones as glucagon or ACTH. Contrariwise, the degradation of insulin by boiled placental extracts does not appear to be enzymatically mediated. The activity is slow, stable, and relatively uninfluenced by variation in the quantity of placental extract or by the temperature of incubation.

\section{Normal values for insulin degradation by hu- man placentas}

In order to establish values for the normal insulin-degrading capacity of human placenta and to obtain control data for future studies of abnormal pregnancies, nine term placentas were assayed on separate days with multiple concentrations of insulin and the standard expcrimental procedure.

Analyses were obtained following 5 and $30 \mathrm{~min}$ utes of incubation. Five different preparations of $I^{131}$-insulin were employed in the nine studies. Values for fractional insulin degradation in systems containing $25,50,100$ and $400 \mu \mathrm{g}$. of crystalline insulin per $\mathrm{ml}$. are presented in Figure 9. Significant differences could not be demonstrated in the insulin-degrading capacities of placentas obtained by vaginal delivery and placentas obtained at elective Caesarian section prior to the inception of labor. Nitrogen content of the $15,000 \times \mathrm{G}$ supernatant solutions derived from these $1: 3$ placental homogenates averaged $423.9 \mathrm{mg}$. N per 100 ml. $\pm 73.1 .^{4}$ For a single experiment, a placenta was obtained at the spontaneous abortion of an 18 week old fetus. An extract prepared from this placenta by the standard experimental procedure contained $233.2 \mathrm{mg}$. N per $100 \mathrm{ml}$. and effected distinct degradation of insulin (Figure 9).

For purposes of comparison, four similar experiments were performed with livers from fed male rats. Mean values for insulin degradation by the $15,000 \times \mathrm{G}$ supernatant solutions of $1: 3$ rat liver homogenates are shown in Figure 9. The insulin-degrading capacities of the rat liver preparations exceeded those of comparably prepared placental extracts. However, since the nitrogen content of the four rat liver extracts averaged $828.9 \mathrm{mg}$. per $100 \mathrm{ml}$., the differences in activities are not as great when expressed on a nitrogen rather than on a wet weight basis.

Conclusions. The studies with the nine term placentas indicate that ranges of normal activity

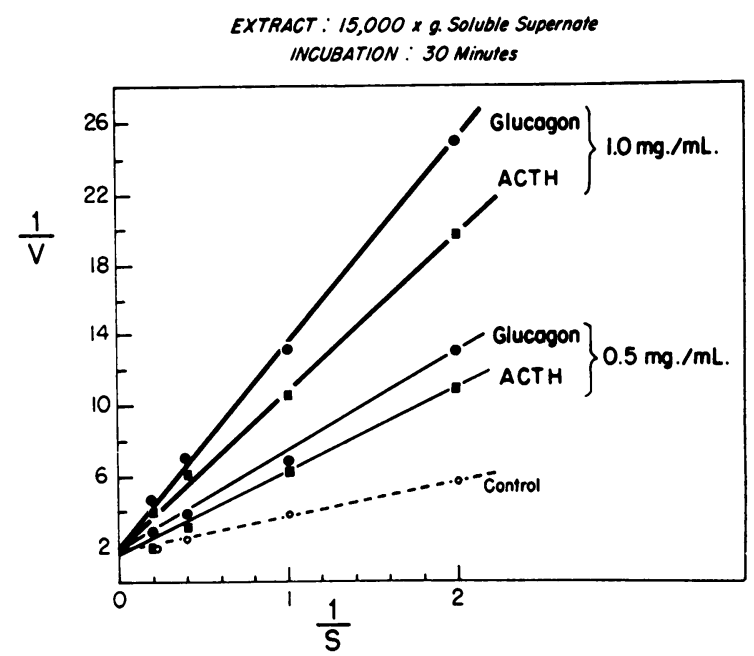

Fig. 8. The Nature of the Inhibition of Placental Insulin Degradation in the Presence of ACTH or Glucagon

Reaction mixture: $2.0 \mathrm{ml}$. pH 7.4 phosphate buffer containing $20.2,40.2$ or $100.2 \mu \mathrm{g}$. insulin per $\mathrm{ml}$., $15,000 \times$ $\mathrm{G}$ placental extract as in standard experimental procedure, and \pm 0.5 or $1.0 \mathrm{mg}$. ACTH or glucagon per $\mathrm{ml}$. $\mathrm{V}=$ units of $\mathrm{I}^{131}$-insulin degraded in 30 minutes of incubation at $38^{\circ} \mathrm{C}$. as judged by the evolution of nonprecipitable $\mathrm{I}^{131}$. $\mathrm{S}=$ units of insulin per $\mathrm{ml}$. of reaction mixture.

${ }^{*}$ Mean \pm standard deviation. 


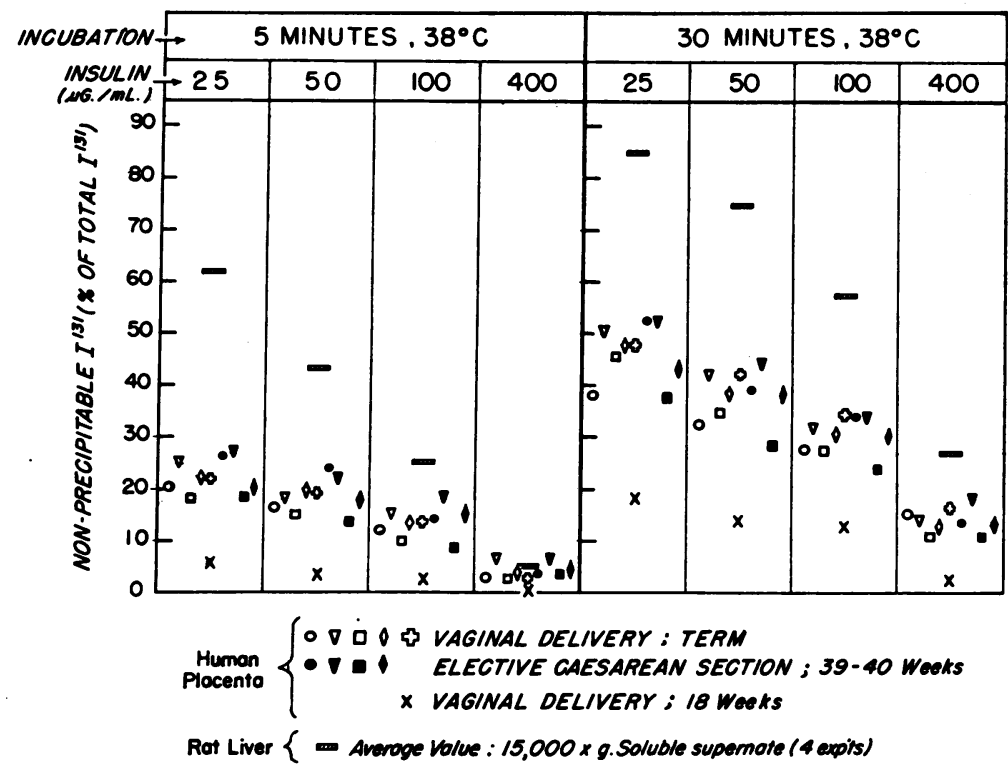

Fig. 9. The Degradation of Insulin by Extracts of Human Placenta and Livers of Fed Male Rats

Details of incubation and preparation of extracts are as in standard experimental procedure. Values for placentas were derived from individual experiments. Cross-hatched bars refer to mean values of four experiments with $15,000 \times \mathrm{G}$ rat liver extracts.

are narrow and that the measurement of insulindegrading capacity represents a reproducible parameter of human placental function. The similar potencies of both Caesarian section and "vaginal delivery" placentas would suggest that insulin degradation does not result from an activation of proteolytic mechanisms during labor. Rather, the manifest activity of the single 18 week placenta may constitute evidence that placental mechanisms for insulin degradation are present at least as early as the second trimester.

\section{DISCUSSION}

The present studies have provided the first detailed in vitro characterization of an insulin-degrading system derived from human tissue. It has been demonstrated that cellular and subcellular preparations of human placenta can degrade $\mathrm{I}^{131}$-insulin into radioactive products which are soluble in TCA, electrophoretically distinct from ionic iodide, and which approximate the chromatographic mobilities of iodinated tyrosines. This evidence for the proteolysis of $\mathrm{I}^{131}$-insulin has been corroborated and extended with unlabeled crystalline insulin. Thus, it has been shown that TCA-soluble, ultraviolet-absorbing products of proteolysis are evolved during incubation of native insulin with human placental extracts. Concomitantly, there is an attenuation of the hypoglycemic potency of the insulin.

Inactivation of insulin by extracts of certain tissues of animal origin has been known for some time (26-29). With the advent of $\mathrm{I}^{131}$-insulin, the mechanisms have been investigated and characterized perhaps most extensively in rat and beef liver preparations $(9-12,20,25,30,31)$. The similarities between the published findings for animal liver "insulinase" and the insulin-degrading system in human placenta are striking. Liver "insulinase," like the placental activity, $a$ ) is localized in the soluble cytoplasm during subcellular fractionation $(20,29,31,32) ; b)$ is inhibited by sulfhydryl reagents $(10,12,26) ; c)$ is reduced by dialysis or storage $(28,29,33)$; and $d)$ contains both heat-stable as well as heat-labile components $(10,20,26,28,32)$. Moreover, in animal liver as in human placenta, the heat-labile component displays the activation energy, reaction kinetics 
and circumscribed $\mathrm{pH}$ dependencies which are characteristic of enzymatic systems $(10,12,25,29$, $30,34)$. Indeed, the Michaelis-Menten constants, based on initial velocities of insulin degradation by rat liver (34) and human placental extracts, are of similar orders of magnitude; only the $\mathrm{pH}$ optima differ. Although all the present studies were conducted at an initial $\mathrm{pH}$ of 7.4 to simulate physiological conditions, maximum placental activity is obtained at $\mathrm{pH} 6.5$ to 7.0. Contrariwise, rat liver "insulinase" is most effective at $\mathrm{pH} 7.6$ to $8.0(10)$. With the crude extracts of liver and placenta which have been employed, these differences are difficult to interpret. However, it should be mentioned that final $\mathrm{pH}$ values were not recorded in any of the previous studies, and hence, the possibility of declining $\mathrm{pH}$ values during incubation of rat liver preparations cannot be excluded.

The available data do not justify conclusions regarding the substrate specificity of the heatlabile placental system, nor can it be stated whether one or several enzymes participate in the manifest cleavage of insulin. Relative specificity is indicated by the fact that equimolar concentrations of a variety of proteins did not appreciably modify reaction kinetics. ${ }^{5}$ For the moment, definitive dissection of the insulin-degrading system of human placenta must await the results of further purification.

Regardless of its biochemical specificity, the physiological implications of this system warrant consideration. The placenta must be regarded, at least, as yet another tissue which can both respond to insulin and degrade insulin. For the placenta, as for other such tissues, it remains to be demonstrated whether local hormonal degradation is linked to insulin action or whether degradation

\footnotetext{
5 The competitive inhibition observed with large quantities of ACTH and glucagon need not indicate a true substrate competition for the insulin-degrading system. In $18,000 \times \mathrm{G}$ extracts of rat liver, $\mathrm{ACTH}$ and glucagon also retard insulin breakdown (25). However, the hepatic enzymes for degrading ACTH and glucagon may be different from "insulinase" $(35,36)$ and "insulinase" in $18,000 \times \mathrm{G}$ rat liver extracts may be competitively inhibited by products of the proteolysis of ACTH or glucagon (30). Thus, if separate enzymes for ACTH and glucagon proteolysis are also present in the $15,000 \times \mathrm{G}$ placental extracts, then similar interrelationships might occur.
}

merely conditions local hormonal activity by regulating the availability of unaltered insulin. In either event, the presence of the placenta as an added site for the irreversible removal of insulin during pregnancy could significantly alter the total insulin demands of the pregnant female. Unless there were commensurate reduction in the extrauterine insulin requirements, the maintenance of hormonal equilibrium in pregnancy would necessitate the absolute availability of increased quantities of insulin. At any given time in pregnancy, the magnitude of the placental contribution to maternal insulin economy ${ }^{6}$ would be conditioned by a) the delivery of insulin to the placenta (i.e., placental blood flow), and $b$ ) the potential insulindegrading capacity of the placenta. The present studies have not documented the level of placental activity throughout human gestation, although manifest degradation was observed with the single 18 week placenta that was available for examination. Concurrent experiments with rats have demonstrated that proteolysis of insulin can be effected by the earliest formed rat placenta and that the activity per milligram of nitrogen in placental extracts remains constant throughout pregnancy (37). Thus, if rat data may be extrapolated to humans, it may be inferred that the contributions of placental insulin degradation to maternal insulin requirements should parallel $a$ ) the vascularity of the placenta, and $b$ ) the total functioning mass of placental tissue. With this in mind, review of the clinical features of the diabetogenic effects of pregnancy may be appropriate.

In human pregnancy, tolerance to intravenous glucose is not significantly altered (38) although the response to exogenous insulin is diminished, especially in the latter half of gestation (33). Presumably, therefore, an increased endogenous secretion of insulin is required for the preservation of normal carbohydrate metabolism during pregnancy. This premise is supported by the clinical sequence in subjects with diminished pancreatic reserve. Thus, frank diabetes mellitus frequently supervenes in prediabetic females during the latter phases of pregnancy, and, despite some conflicting

\footnotetext{
${ }^{6}$ Since there are at present no experimental data relevant to the fetal elaboration or the transplacental passage of insulin in primate pregnancy, these factors have been omitted from the above theoretical considerations.
} 
reports (39), the maintenance requirements for insulin of pregnant diabetics are often increased at this time (4-8). Indeed, both Pedersen (5) and Bergqvist (7) observed the greatest augmentation of maintenance insulin requirements during the seventh month, a time at which the placenta is nearly fully developed, senescent vascular changes in the placenta have not yet occurred, the heightened cardiac output of pregnancy is at peak level (40), and, by inference, placental perfusion is maximal. The expulsion of the conceptus is followed by a prompt reversion of the diabetogenic effects of pregnancy. Insulin requirement of diabetic patients may decline precipitously in the immediate postpartum period and normoglycemia may return in prediabetic subjects (4-8). Although the latter phenomenon can be attributed in part to diminished food intake and the heightened muscular effort of labor, studies with intact rats in this laboratory would indicate that a true alteration in insulin metabolism occurs (37). Near term, in the rat, there is an acceleration in the fractional rate of turnover of labeled insulin which cannot be explained on the basis of transplacental loss of intact insulin, and which disappears within hours following parturition. Thus, from all the clinical evidence, some correlation does seem to obtain between insulin requirements and the presence and the level of function of an intrauterine insulin-degrading site.

However, alternative mechanisms could also explain these clinical findings. Among the extrauterine possibilities that have been suggested, the case for contra-insulin factors of pituitary origin is somewhat weakened by the recent studies of a woman who was hypophysectomized during pregnancy (41). In this patient, while on constant thyroid and cortisone replacement therapy, glucose tolerance was abnormal and response to intravenous insulin was diminished at 31 weeks of gestation whereas both tests were normal 5 days postpartum. Similarly, the case for adrenal contra-insulin factors is hard to reconcile with the fact that levels of blood glucocorticoids remain elevated in the immediate postpartum period (42) despite the occasional acute reduction in insulin requirements of diabetics. As a matter of fact, the whole concept of increased adrenocortical activity during pregnancy has recently been challenged (43).
From all considerations, it would appear that the temporal relationships are most consonant with an intrauterine basis for the diabetogenic effects of pregnancy. Mediation could be effected by $a$ ) placental (or even fetal) elaboration of contrainsulin factors or $b$ ) placental (or even fetal) degradation of insulin. The present studies do not aid in differentiating between the secretory and the degradatory possibilities. Insofar as mechanisms have now been demonstrated for the proteolysis of insulin by placenta, an experimental basis has been provided for the latter possibility. ${ }^{7}$ However, such degradation need not be confined to insulin. By analogy to other tissues, the placenta might also contain enzymatic mechanisms for the proteolysis of glucagon or pituitary principles which affect pancreatic cell activity. Moreover, the alternatives of intrauterine secretion or degradation need not be mutually exclusive. It is doubtful whether any metabolic change in as complex an event as mammalian pregnancy can ever be explained in terms of a single mechanism. From the present data, it may only be suggested that alterations in hormone economy secondary to hormone degradation within the conceptus warrant consideration in any analysis of gestational changes in carbohydrate metabolism.

\section{SUM MARY}

1. The presence of a system for the proteolytic inactivation of insulin has been demonstrated in human placental tissue.

2. During incubation of insulin with cellular and subcellular preparations of human placenta, insulin is degraded into trichloroacetic acid-soluble, ultraviolet-absorbing products of proteolysis. Concomitantly, the hypoglycemic potency of insulin is attenuated.

3 . The system has been characterized with $\mathrm{I}^{131}$ insulin and cell-free placental extracts. It has been demonstrated that placental insulin-degrading activity is localized within the soluble, nonparticu-

7 The placental insulin-degrading system may also provide a means of studying one of the suggested etiologies of diabetes mellitus. Mirsky has postulated that increased degradation of insulin could antedate manifest diabetes mellitus and constitute the insulinogenic challenge in the prediabetic state $(29,30)$. The placenta may be proposed as an easily accessible human tissue wherein this thesis may be experimentally evaluated in subjects with large babies or other prediabetic stigmata. 
late cytoplasm and consists of heat-stable and heatlabile components. The heat-labile activity effects most of the rapid inactivation of insulin and exhibits properties that are characteristic of enzymatic mechanisms. At $38^{\circ} \mathrm{C}$., and $\mathrm{pH} 7.4$, the Michaelis-Menten constant $(\mathrm{Km})$ for the reaction was found to be $3.8 \times 10^{-7}$ Moles per L., and $V_{\max }$ was $11.0 \mu \mathrm{g}$. per minute per $\mathrm{Gm}$. of wet weight of placenta.

4. The activities of multiple normal term placentas were assayed at various concentrations of insulin in order to obtain control data for future studies of abnormal pregnancies. It was demonstrated that insulin-degrading capacity constitutes a reproducible parameter of human placental function. Manifest activity was displayed by a single placenta obtained at the spontaneous abortion of an 18 week old fetus.

5. The insulin-degrading system of human placenta has been compared to liver "insulinase" preparations of animal origin.

6 . It has been suggested that proteolytic inactivation of protein hormones within the conceptus may be of physiological significance in the gestational changes in carbohydrate economy.

\section{ACKNOWLEDGMENTS}

The excellent technical assistance of Miss Wilma Barshaw and the secretarial services of Miss Susan Colby are gratefully acknowledged. The authors are also indebted to Dr. Fred M. Snell for his suggestions in the studies of enzyme kinetics and to Dr. Benjamin Tenney, Chief of the Obstetrical Service of the Boston City Hospital, and the members of his 1956-1958 resident staff whose constant cooperation made this study possible.

\section{REFERENCES}

1. Freinkel, N., and Goodner, C. J. The metabolism of insulin by human placental tissue (abstract). J. clin. Invest. 1958, 37, 895.

2. Hurwitz, D., and Jensen, D. Carbohydrate metabolism in normal pregnancy. New Engl. J. Med. 1946, 234, 327.

3. White, P. Symposium on diabetes mellitus; pregnancy complicating diabetes. Amer. J. Med. 1949, 7, 609.

4. Katsch, G. Schwangerschaft als Belastungsprobe für Diabetikerinnen. Zbl. Gynäk. 1950, 72, 1756.

5. Pedersen, J. Course of diabetes during pregnancy. Acta endocr. (Kbh.) 1952, 9, 342.

6. Hoet, J. P., and Lukens, F. D. W. Carbohydrate metabolism during pregnancy. Diabetes $1954,3,1$.
7. Bergqvist, N. The influence of pregnancy on diabetes. Acta endocr. (Kbh.) 1954, 15, 166.

8. Hagbard, L. Pregnancy and diabetes mellitus. Acta obstet. gynec. scand. 1956, 35, suppl. I.

9. Mirsky, I. A., Perisutti, G., and Dixon, F. J. Destruction of $\mathrm{I}^{131}$-labeled insulin by liver slices. Proc. Soc. exp. Biol. (N. Y.) 1954, 86, 228.

10. Mirsky, I. A., Perisutti, G., and Dixon, F. J. The destruction of $\mathrm{I}^{131}$-labeled insulin by rat liver extracts. J. biol. Chem. 1955, 214, 397.

11. Tomizawa, H. H., Nutley, M. L., Narahara, H. T., and Williams, R. H. Inactivation of insulin by rat liver extracts. J. Amer. chem. Soc. 1954, 76, 3357.

12. Tomizawa, H. H., Nutley, M. L., Narahara, H. T., and Williams, $R$. $H$. The mode of inactivation of insulin by rat liver extracts. J. biol. Chem. 1955, 214, 285.

13. Gleason, Geoffrey I. Abbott Radio-Pharmaceuticals, Oak Ridge division. Personal communication.

14. Berson, S. A., Yalow, R. S., Bauman, A., Rothschild, M. A., and Newerly, K. Insulin- $\mathrm{I}^{131}$ metabolism in human subjects: Demonstration of insulin binding globulin in the circulation of insulin treated subjects. J. clin. Invest. 1956, 35, 170.

15. Martin, D. B., Renold, A. E., and Dagenais, Y. M. An assay for insulin-like activity using rat adipose tissue. Lancet 1958, 2, 76.

16. Freinkel, N., Dowling, J. T., and Ingbar, S. H. The interaction of thyroxine with plasma proteins: Localization of thyroxine-binding protein in Cohn fractions of plasma. J. clin. Invest. 1955, 34, 1698.

17. Dowling, J. T., and Goodner, C. J. Electronic ana$\log$ integrator for simultaneous linear and integral graphic data recording. In preparation.

18. Nelson, N. A photometric adaptation of the Somogyi method for the determination of glucose. J. biol. Chem. 1944, 153, 375.

19. Ferrebee, J. W., Johnson, B. B., Mithoefer, J. C., and Gardella, J. W. Insulin and adrenocorticotropin labeled with radio-iodine. Endocrinology 1951, 48, 277.

20. Narahara, H. T., Tomizawa, H. H., Miller, R., and Williams, R. H. Intracellular distribution of an insulin-inactivating system of liver. J. biol. Chem. 1955, 217, 675

21. Burrows, B. A., Peters, T., and Lowell, F. C. Physical binding of insulin by gamma globulins of insulin-resistant subjects. J. clin. Invest. 1957, 36, 393.

22. Newerly, K., and Berson, S. A. Lack of specificity of insulin- ${ }^{181}$-binding by isolated rat diaphragm. Proc. Soc. exp. Biol. (N. Y.) 1957, 94, 751.

23. Goodner, C. J., Ingbar, S. H., and Freinkel, N. The inhibition of insulin degradation by plasma fractions of nondiabetic sera (abstract 71). Program of the fortieth meeting of the Endocrine Society, San Francisco, Calif. 1958. 
24. Kallee, E. Über ${ }^{131} \mathrm{~J}$-signiertes Insulin, I Mitteilung (Nachweis). Z. Naturforsch. 1952, 7 B, 661.

25. Tomizawa, H. H., and Williams, R. H. Studies on the specificity of an insulin-inactivating system of the liver. J. biol. Chem. 1955, 217, 685.

26. Mirsky, I. A., and Broh-Kahn, R. H. The inactivation of insulin by tissue extracts. I. The distribution and properties of insulin inactivating extracts. (Insulinase.) Arch. Biochem. 1949, 20, 1.

27. Schmidt, A. A., and Saatchian, R. L. Effect of some tissues of the animal organism on the activity of insulin. Ž. exp. Biol. med. 1929, 11, 42, as quoted in Chem. Abst. 1930, 24, 4859.

28. Lehmann, $H$., and Schlossmann, $H$. The action of cell-free muscle extract on insulin. J. Physiol. 1938, 94, 15P.

29. Mirsky, I. A. The insulinase and insulinase-inhibitor activity of the liver. Ciba Found. Coll. Endocr. 1953, 6, 263.

30. Mirsky, I. A. Insulinase, insulinase-inhibitors, and diabetes mellitus. Recent Progr. Hormone Res. 1957, 13, 429.

31. Vaughan, $M$. The inactivation of insulin by an enzyme from rat liver. Biochim. biophys. Acta 1954, $15,432$.

32. Beyer, R. E. A study of insulin metabolism in an insulin tolerant strain of mice. Acta endocr. (Kbh.) 1955, 19, 309.

33. Burt, R. L. Peripheral utilization of glucose in pregnancy. III. Insulin tolerance. Obstet. and Gynec. 1956, 7, 658.

34. Yalow, R. S., and Berson, S. A. Apparent inhibition of liver insulinase activity by serum and serum fractions containing insulin-binding antibody. J. clin. Invest. 1957, 36, 648.

35. Mirsky, I. A., and Perisutti, G. The relative specificity of the insulinase activity of rat liver extracts. J. biol. Chem. 1957, 228, 77.

36. Tomizawa, H. H., and Halsey, Y. D. Isolation of an insulin-degrading enzyme from beef liver. J. biol. Chem. 1959, 234, 307.

37. Goodner, C. J., and Freinkel, N. The effect of pregnancy on insulin metabolism in the rat. Clin. Res. 1959, 7, 247.

38. Burt, R. L. Peripheral utilization of glucose in pregnancy and the puerperium. Obstet. and Gynec. 1954, 4, 58.

39. Patterson, M., and Burnstein, N. Diabetes and pregnancy. A clinical analysis. Arch. intern. Med. 1949, 83, 390.

40. Bader, R. A., Bader, M. E., Rose, D. J., and Braunwald, E. Hemodynamics at rest and during exercise in normal pregnancy as studied by cardiac catheterization. J. clin. Invest. 1955, 34, 1524.

41. Little, B., Smith, O. W., Jessiman, A. G., Selenkow, H. A., Van't Hoff, W., Eglin, J. M., and Moore, F. D. Hypophysectomy during pregnancy in a patient with cancer of the breast: Case report with hormone studies. J. clin. Endocr. 1958, 18, 425.

42. Bayliss, R. I. S., Browne, J. C., Round, B. P., and Steinbeck, A. W. Plasma-17-hydroxycorticosteroids in pregnancy. Lancet 1955, I, 62.

43. Migeon, C. J., Bertrand, J., and Wall, P. E. Physiological disposition of 4-C ${ }^{14}$-cortisol during late pregnancy. J. clin. Invest. 1957, 36, 1350. 